\title{
New Rationales for Women on Boards
}

\section{Barnali Choudhury}

\section{Introduction}

The impetus for increasing the number of women on boards of directors is quickly gaining momentum across Europe and the world. Already several European states have mandated female presence on boards through the imposition of quotas, while several other countries, such as the United States and Australia, have taken notice of the issue and are working to combat this problem through alternative means.

In the U.K., initiatives to increase female representation on board have been mainly directed at suggested targets and other non-mandatory recommendations. In particular, in a government-backed report, Lord Davies of Abersoch recommended that FTSE 100 boards strive for at least 25 percent female representation on boards by $2015 .^{1}$ Two years after the release of Lord Davies' report, however, concerns remain. While the number of women on boards of FTSE 100 companies has increased, many boards still remain all-male and, at the current rate of progress, the goal of 25 percent is unlikely to be attained. ${ }^{2}$

The slow pace of change has not gone unnoticed. The European Commission has recently released a series of recommendations aimed at quick changes in this area, ${ }^{3}$ while Lord Davies has charged that the slow rate of change is a result of managerial attitudes at

\footnotetext{
${ }^{1}$ Lord Davies of Abersoch, Women on Boards - February 2011 (Department of Business Innovation and Skills, 2011).

${ }^{2}$ Cranfield School of Management, The Female FTSE Board Report 2013: False Dawn of Progress for Women on Boards? (Cranfield University, 2013) 11, 13.

${ }^{3}$ European Commission, 'Women on Boards: Commission proposes $40 \%$ objective' (14 Nov 2012)

<http://ec.europa.eu/justice/newsroom/gender-equality/news/121114_en.htm> accessed 2 October 2013.
} 
some of Britain's largest companies. Labelling them "prehistoric monsters", he has observed that these men "just don't get equality". ${ }^{4}$

Yet, despite the market's apparent lack of interest in increasing the number of women on boards, the government continues to couch its initiatives in this area almost exclusively in economic based justifications. It is perhaps no wonder then why managers fail to understand the equality issues underpinning the broader topic of women on boards when the main report recommending this change avoids these issues almost entirely.

Conversely, this article argues that rationales for increasing women on boards should be based on both equality and economics grounds. As Lord Davies' comments have indicated, part of business' slow take-up of his recommendations is due to a failure to understand the root causes of the lack of gender diversity on boards. Without a greater understanding of the problem, and the issues that give rise to the status quo of fewer women on boards, it is not surprising that companies are wary of adopting the suggested solutions to a problem that they may not have understood or even been aware of. Equality based rationales may therefore clarify the problem for businesses.

However, relying primarily on equality arguments to rationalise an initiative that promotes women on boards presents difficulties as well. Boards of directors, are, after all, constituted to promote the success of the company for the benefit of shareholders. ${ }^{5}$ Their primary task is, accordingly, wealth maximization. ${ }^{6}$ Thus, as the very role and function of the board is economic in nature, increasing the number of women on boards must similarly be rationalised in economics.

\footnotetext{
${ }^{4}$ Louise Peacock, 'Lord Davies shakes-up Britain's boardrooms' The Telegraph (London, 18 Feb 2012) <http://www.telegraph.co.UK/finance/jobs/9090327/Lord-Davies-shakes-up-Britains-boardrooms.html> accessed 1 October 2013

${ }^{5}$ Companies Act 2006, s 172.

${ }^{6}$ Company Law Review Steering Group, Modern Company Law for A Competitive Economy: The Strategic Framework (DTI 1999) para. 5.1.12
} 
At the same time, the most commonly relied upon economic justification for increasing the number of women on corporate boards - the relationship between women's presence on boards and firm financial performance - does not necessarily support initiatives in this area. While some empirical studies have found a causal connection between female representation on boards and positive firm financial performance, others have not. ${ }^{7}$ Thus, the equivocal nature of the classic "business case" for increasing female representation on boards demands that a new rebolstered economic rationale be found.

One approach for a new economic rationale is to focus, not on the effects of female directors on financial performance, but on the contributions that female directors can make to the board decision-making process. Under this rationale, if women's presence on boards makes boards more effective decision-makers, increasing the number of women on boards will be economically justified.

Accordingly, this article argues that initiatives to increase the number of women on boards should be rationalised both in terms of equality and in terms of the contributions women can make to the board decision-making process. It makes this argument in three parts. First, it begins by reviewing the government's current efforts at addressing the lack of female representation on boards and examines the results of these efforts. Given the shortcomings of the current efforts, it argues in favour of improving the rationales for the government's recommendations as a means of prompting normative changes in companies. Second, it illustrates the content of the two new rationales by discussing both the need and

\footnotetext{
${ }^{7}$ David A. Carter et al., 'Corporate Governance, Board Diversity, and Firm Value' (2003) 38:1 F. Rev. 33; Niclas L. Erhardt et al., 'Board of Director Diversity and Firm Financial Performance' (2003) 11 C.G. 102; Kathleen A. Farrell and Philip L. Hersch, 'Additions to Corporate Boards: The Effect of Gender', (2005) 11 J. of Corp. F. 85; Renee B. Adams and Daniel Ferreira, 'Women in the Boardroom and Their Impact on Governance and Performance' (2009) 94 J. of Financial Econ. 291, 292; David A. Matsa and Amalia R. Miller,' A Female Style in Corporate Leadership? Evidence from Quotas' (2013) 5(3) Amer. Econ. J.: Applied Econ. 136; Kenneth R. Ahern and Amy K. Dittmar, 'The Changing of the Boards: The Impact on Firm Valuation on Mandated Female Representation' (2012) 127:1 Q. J. Econ. 137; Harald Dale-Olsen et al, 'Women on Boards of Directors and Firm Performance' in Frederik Engelstad and Mari Teigen (eds.), Firms, Boards and Gender Quotas: Comparative Perspectives (Emerald Group Publishing Ltd. 2012) 211; M. Schwartz-Ziv, 'Does the Gender of Directors Matter?', Edmond J. Safra Working Papers, No. 8 (March 2013) <http://papers.ssrn.com/sol3/papers.cfm?abstract_id=2257867> accessed 1Oct 2013.
} 
the particular benefits of an equality rationale, by drawing from Rawl's theory of justice, before offering a reoriented economic rationale that focuses on women's contributions to board effectiveness. Finally, it turns to examine methods by which gender diversity on boards can be fostered which align with the equality and the reoriented economic rationales discussed in the earlier section. It concludes that while quotas do not necessarily accord with the earlier offered rationales, there are several other mechanisms that do.

\section{The Need to Bolster the Rationales for Women on Boards}

While the U.K. government has been diligent about efforts to increase women on boards, it has not been successful in effectuating substantial changes to the number of women on boards. As all of the government's efforts in this area consist of suggestions or targets that are purely voluntary in nature, adoption of these initiatives is highly dependent on companies' normative approach to inclusion of women in business. For this reason, the government's initiatives must be supported by new and bolstered rationales.

\section{A. Initiatives to Foster Women on Boards}

As early as 2003, Derek Higgs, in his review of non-executive directors, observed that the low number of female directors was "striking". At the time, only six per cent of nonexecutive board memberships were held by women, even though 30 percent of managers were female. ${ }^{9}$ Higgs recommended that in making appointments, future boards should draw from pools of qualified women. ${ }^{10}$ The Tyson Report, commissioned by the government following the publication of the Higgs Review, similarly advocated for broader approaches to

\footnotetext{
${ }^{8}$ Derek Higgs, Review of the Role and Effectiveness of Non-Executive Directors (DTI 2003) para. 10.22.

${ }^{9}$ ibid para. 10.22

${ }^{10}$ ibid para. 10.25
} 
recruitment of non-executive directors as a means of attracting more female candidates to boards. $^{11}$

More recently, the U.K. Corporate Governance Code expanded upon and codified Higgs' recommendation. In June 2010, the government introduced principles for corporate governance effectiveness, which, among other things, dealt with board appointments. The Code now provides that the search for board candidates should be conducted and appointments made with "due regard for the benefits of diversity on the board, including gender". ${ }^{12}$ However, as the Code is structured on a "comply or explain" basis, companies need not adhere to this principle if they provide an explanation to their members for their reasons for doing so.

In 2010, the Coalition government also added gender diversity to boards as part of their mandate. Specifically pledging "to promote gender equality on the boards of listed companies" in hopes of building "a fairer society", the government appointed Lord Davies of Abersoch to head up an initiative to review the current status of female representation on boards and to make recommendations. ${ }^{13}$

The data revealed that efforts to bolster gender diversity on boards were sorely needed. At the time of Lord Davies' appointment, women represented only 12.5 percent of all FTSE 100 directors and 7.8 percent of FTSE 250 directors. ${ }^{14}$ In addition, 21 percent of FTSE 100 and 52.4 percent of FTSE 250 companies consisted of exclusively male boards, only 2 percent of chairs of FTSE 100 companies were women, and only 13.3 percent of new

\footnotetext{
${ }^{11}$ Louise Tyson, The Tyson Report on the Recruitment and Development of Non-Executive Directors (London Business School 2003).

${ }^{12}$ Financial Reporting Council, The U.K. Corporate Governance Code (2010), Principle B.2.

${ }^{13}$ Cabinet Office, The Coalition: Our Programme for Government (2010)

<www.infrastruct.co.UK/downloads/govpr1.pdf/> accessed 1 October 2013; Lord Davies (n 1).

${ }^{14}$ Lord Davies (n 1) 7.
} 
appointments were made to women. ${ }^{15}$ At the same time, women in the basic labour force accounted for 45 percent. $^{16}$

Based on these findings, Lord Davies made ten recommendations in a February 2011 government-backed report. Specifically, he recommended that FTSE 100 boards increase female board representation to at least 25 percent by 2015 by aiming to fill one-third of all new board appointments with women; that listed companies establish a policy on boardroom diversity, including measurable objectives for implementing the policy; that quoted companies disclose statistics on women in boards and in senior positions in their companies and disclose how diversity is germane to a board's nominating process; and that companies consider women for board appointments whose experience is garnered outside the corporate mainstream. ${ }^{17}$

\section{B. The Effects of the Government Initiatives}

Two years after Lord Davies' report was released, the Cranfield School of Management reviewed the effects of his recommendations. ${ }^{18}$ While their review indicated that some progress had been made, the data revealed that substantial changes to the inclusion of women on boards had not yet been achieved and that many companies were failing, in whole or in part, to adhere to the government's initiatives.

The review found that the number of women on boards had increased to 17 percent on FTSE 100 companies and 13 percent on FTSE 250 companies. Nevertheless, six percent of FTSE 100 and just under 30 percent of FTSE 250 boards still remained exclusively male. ${ }^{19}$

\footnotetext{
${ }^{15}$ ibid 11 and 13 .

16 ibid 9.

17 ibid 18-22.

${ }^{18}$ Cranfield School of Management (n 2).

19 ibid 11, 13, 37.
} 
Moreover, only 25 percent - and not the Lord Davies recommended 33 percent - of all new appointments were made to women. ${ }^{20}$

A 2012 review further revealed that while increases in whole numbers were apparent, normative changes were less visible. ${ }^{21}$ For example, only 38 FTSE 100 and 34 FTSE 250 companies set targets for the number of women they aim to have on their boards by $2015 .^{22}$ Moreover, 37 companies categorically stated that they would not be setting targets. ${ }^{23}$ Most companies also declined to disclose statistics about the number of women at every level of their organisation, to provide clear reporting arising out of their diversity policies, or to disclose whether they even have such a policy. ${ }^{24}$

Even more importantly, however, it is unclear whether the increases that have been made to gender diversity on boards are because companies suddenly - to use Lord Davies' words - "get equality" or because of the increased media attention the issue has received. If it is the latter - and the number of companies that have failed to prioritise diversity issues by setting targets or adopting diversity policies suggests that it is - then the momentum needed to achieve gender parity on boards over the next five years may not be achieved if media attention to this issue is diverted or if the threat of quotas, looming in the background, dissipates.

\section{Moving Away from Primarily an Economic Rationale}

The lack of normative changes to include gender diversity within company objectives suggests that despite small increases to the number of women on boards, the ability to

\footnotetext{
${ }^{20}$ ibid 20.

${ }^{21}$ Cranfield School of Management, Female FTSE Board Report 2012: Milestone or Millstone? (Cranfield University 2012).

${ }^{22}$ ibid 30, 44.

23 ibid.

${ }^{24}$ ibid $34,46$.
} 
achieve lasting gender parity on boards of directors is at risk. In part, this may be a result of the sole reliance on economic-based rationales offered to incentivise companies to take action. However, economic rationales, standing alone, are unlikely to persuade companies to strive for gender diversity in the boardroom.

The reasons for this are three-fold. First, normative changes to corporate policies that effect substantive company behaviour are often not driven by economic rationales. Researchers have found that decision-making related to equity issues is not dependent on rational decisions ${ }^{25}$ and that ethical justifications can be the primary instigator of organizational change. ${ }^{26}$ Many companies embracing efforts to promote female candidates may be thus more likely to be prompted into action by moral or justness concerns. ${ }^{27}$ For instance, in supporting the women in boards initiative, Marcus Agius, Chairman of Barclays, specifically notes that "... prioritising gender balance in ...organisations... is the right thing to do. $" 28$

Second, relying on economic rationales may have served to mask some of the problems propelling the issues surrounding gender diversity on boards. People involved in the selection of candidates have been found to be subject to unconscious or ingrained biases towards individuals of different genders. ${ }^{29}$ As these biases are unintentionally generated and may even contradict an individual's philosophies and beliefs, individuals may not even be

\footnotetext{
${ }^{25}$ Mike Noon, 'The Fatal Flaws of Diversity and the Business Case for Ethnic Minorities' (2007) 21:4 Work, Emp. and Soc'y 773, 779 (noting that decision-making on equity issues was largely made on an intuitive basis rather than through a cost-benefit analysis).

${ }^{26}$ Colin McLaughlin and Simon Deakin, 'Equality Law and the Limits of the 'Business Case' For Addressing Gender Inequalities'(2011) University of Cambridge - Working Paper No. 420, 13 <http://www.cbr.cam.ac.uk/pdf/WP420.pdf> accessed 2 October 2013.

${ }^{27}$ Siri Terjesen et al., 'Women Directors on Corporate Boards: A Review and Research Agenda (2009) 17:3 C.G. 320, 331; J.Cunyon Gordon, 'Painting by Numbers: “And, Um, Let's Have a Black Lawyer Sit at Our Table", (2003) 71 Fordham L. Rev. 1257, 1277.

${ }^{28}$ Cranfield School of Management (n 21) 3. McLaughlin and Deakin similarly report that in their study they found that companies would seek more women at senior levels because it was the right thing to do. See McLaughlin and Deakin (n 26) 13.

${ }^{29}$ Howard Ross, 'Proven Strategies for Addressing Unconscious Bias in the Workplace' (CDO Insights, Aug. 2008) <http://www.cookross.com/docs/UnconsciousBias.pdf> accessed 1 October 2013; Nancy M. Carter and Christine Silva, 'Women in Management: Delusions of Progress' (2010) 88:3 Harv. Bus. Rev.19; Noon (n 25) 779.
} 
aware that they possess these biases. ${ }^{30}$ Commentators have speculated that such biases may be limiting efforts at increasing the number of women on boards. ${ }^{31}$ This is because director selection is heavily influenced by notions of trust or reliability which generally arise due to personal relationships. ${ }^{32}$ However, where a personal relationship is not present, similarities between the candidate and the selector, such as gender, become proxies for trust. As a result an economic rationale, such as selecting the most trustworthy candidate, can enable the company to ignore or discount any evidence of an unconscious bias.

Finally, an economic rationale, on its own, may not be sufficient for effecting change in this area because the most common economic rationale used to justify gender diversity on boards is, in and of itself, unconvincing. As indicated earlier, the studies demonstrating a correlation between gender diversity on boards and firm financial performance have been mixed. Several researchers have found that empirical evidence of this correlation is difficult to ascertain due to issues with data collection and difficulties with interpreting causation ${ }^{33}$ while others have noted that identifying the true causal effects of women on boards is "methodologically challenging". ${ }^{34}$ Still others have concluded that it is generally difficult to demonstrate a direct relationship between board composition and firm performance ${ }^{35}$ or to measure the benefits of gender diversity at all. ${ }^{36}$ Indeed, one group of researchers has even

\footnotetext{
${ }^{30}$ Anthony G. Greenwald and Linda H. Krieger, 'Implicit Bias: Scientific Foundations' (2006) 94 CLR 945, 951.

${ }^{31}$ Cheryl L. Wade, 'Corporate Governance as Corporate Social Responsibility: Empathy and Race Discrimination' (2002) 76 Tul. L. Rev. 1461,1473; Carter and Silva (n 29); Thomas W. Joo, 'A Trip Through the Maze of Corporate Democracy: Shareholder Voice and Management Composition' (2003) 77 St. John's L. Rev. 735, 742.

${ }^{32}$ Rosabeth M. Kanter, Men and Women of the Corporation (Basic Books 1977) 48-49; J. Robert Brown, Jr, 'Neutralizing the Board of Directors and the Impact on Diversity' (2011) Denver Legal Studies Research Paper No. 11-18, 2-3 <http://papers.ssrn.com/sol3/papers.cfm?abstract_id=1938427> accessed 1 October 2013; Joo (n 31) $742-744$.

${ }^{33}$ Linda L. Broome and Kim D. Krawiec, 'Signaling Through Board Diversity: Is Anyone Listening?' (2008) 77 U. Cin. L. Rev. 431, 433-434; Adams and Ferreira (n 7) 292; Caspar Rose, 'Does Female Board Representation Influence Firm Performance? The Danish Evidence' (2007) 15 C.G. 404, 412.

${ }^{34}$ Dale-Olsen et al. (n 7) 227.

${ }^{35}$ See e.g. Dan R. Dalton et al., 'Meta-Analytic Reviews of Board Composition, Leadership Structure, and Financial Performance' (1998) 19 Strategic Management J. 269.

${ }^{36}$ Noon (n 25) 777.
} 
concluded that a relationship between these two variables may never be found.$^{37}$ In any case, the almost exclusive reliance on economics in Lord Davies' report has not prompted most British companies to make substantive changes to their practices. Consequently, as it turns out, an exclusive focus on economics to support gender diversity on boards is insufficient.

Instead, while acknowledging the importance of an economic rationale, this article argues that gender diversity on board initiatives should also be grounded in non-economic rationales as well. To that end, the next section examines an equality rationale for these initiatives, and given the shortcoming of the dominant economic rationale, also devises a rebolstered economic rationale.

\section{New Rationales for Gender Diversity on Boards}

Although initiatives fostering gender diversity on boards in the U.K. have been mainly justified on economic grounds, there is some indication of the importance of non-economic rationales in this regard as well. These have not been forgotten, but - standing in the shadow of the preferred economic rationale - severely downplayed. The Coalition government, which appointed Lord Davies, for instance, pledged to promote gender equality on boards as a means of countering the many "barriers to equal opportunities in Britain". ${ }^{38}$ Similarly, the House of Lords EU Select Committee noted that there is a "public interest in ensuring that opportunities are available to all, regardless of gender". ${ }^{39}$ Even Lord Davies, who seems

\footnotetext{
${ }^{37}$ David A. Carter et al., 'The Gender and Ethnic Diversity of US Boards and Board Committees and Firm Financial Performance' (2010) 18 C.G. 396, 411. Brown also argues that a relationship between firm value and diversity will not be found where the board exercises only a monitoring, and not an advisory, function. See Brown (n 32) 21.

${ }^{38}$ Cabinet Office (n 13).

${ }^{39}$ House of Lords - European Union Committee, Women on Boards, 5th Report of Session 2012-13 (9 Nov 2012) 13.
} 
wary of non-economic rationales, admits that the issue is "as much about improving business performance as about promoting equal opportunities for women". ${ }^{40}$

In truth, there are two rationales justifying gender diversity on boards: equality and economics. Under an equality rationale, gender diversity on boards is justified by the need to equalise power and opportunities between men and women; while under an economic rationale, gender diversity on boards is justified by the contributions women can make to companies. That is, an equality rationale justifies initiatives promoting women on boards in terms of justice, while economic arguments are utilitarian in nature and treat issues of justice only indirectly. ${ }^{41}$ However, the two rationales need not remain distinct in that issues of justice may become utilitarian in nature as a signalling device or as a means of enhancing corporate reputation.

Nevertheless, while a utility rationale - even if it incorporates elements of justice remains important for a business initiative such as gender diversity on boards, it is equally important to understand the issue in terms of equality as well. This is because it improves the theoretical soundness and grounding of the modes of reform, determines the scope and legitimacy of the actions needed to achieve gender equality, and determines the necessary level of participation by women. ${ }^{42}$ Most importantly though, an equality rationale promotes gender diversity on boards as a desired value in and of itself and it is this kind of value recognition that may prompt normative changes in businesses.

\section{A. Equality Rationale}

As understanding an initiative such as gender diversity on boards in terms of equality posits numerous benefits, it seems prudent to elaborate upon the precise nature of this rationale.

\footnotetext{
${ }^{40}$ Lord Davies (n 1) 7.

${ }^{41}$ Mari Teigen, 'The Affirmative Action Controversy' (2000) 8:2 NORA - Nordic J. of Fem. and Gender 63, 64.

${ }^{42}$ Kate Malleson, 'Justifying Gender Equality on the Bench: Why Different Won’t Do' (2003) 11 Fem. L.S.1.
} 
Justifying gender diversity on boards from an equality standpoint begins with a claim for an equal or balanced society - or, in other words - a society in which there is a just distribution of power and resources, participation and influence between men and women.

In fact, initiatives fostering gender diversity on boards are particularly well-directed towards redistributing power. Directorships, it must be recalled, are important sources of power and influence. As a member of the Norwegian government recognised during the debate on whether quotas should be introduced for Norwegian boards:

In a society where market forces might be said to be more important than ever before, it is even more important that women are well represented where the power is situated within the companies and the boards. ${ }^{43}$

Calls for an equal or balanced society may also be usefully premised on a Rawlsian framework of justice, or the agreed principles in a social contract by which rational persons would further their interests. ${ }^{44}$ Indeed, this view may be read so as to suggest that equality between genders would have been an agreed principle chosen behind a veil of ignorance. ${ }^{45}$ For this reason, equality between genders can be viewed as an aspect of a just society.

Still, justifying gender initiatives on boards in terms of equality does not necessarily signify an apt redistribution of power and resources only when it results in parity representation of women. Instead, an equality rationale, routed in notions of justice, simply contends that women must have the same opportunities as men to participate at leadership levels in business. ${ }^{46}$

Rawls' second principle of justice underscores the importance of couching efforts to achieve justice in terms of promoting equal opportunities. As he argued, offices and

\footnotetext{
${ }^{43}$ T. Giske, Member of Parliament as quoted in Hilde Bjørkhaug and Siri O. Sørensen, 'Feminism without Gender? Arguments for Gender Quotas on Corporate Boards in Norway' in Engelstad and Teigen (n 7) 198. ${ }^{44}$ John Rawls, A Theory of Justice, rev'd ed. (Harvard University Press 1999) 4, 10.

45 ibid 11. While Rawls did not consider gender in his work, he later argued in its favour. See John Rawls, Justice as Fairness: A Restatement (Harvard University Press 2001) 66.

${ }^{46}$ Nancy Fraser, 'Social Justice in the Age of Identity Politics: Redistribution, Recognition and Participation' in Nancy Fraser and Axel Honneth (eds.) Redistribution or Recognition? A Political Philosophical Exchange (Verso 2003)101; Malleson (n 42) 17.
} 
positions should be available to all under conditions of fair equality of opportunity. ${ }^{47}$ That is, offices and positions should not only be "open in a formal sense", but the chance to attain these positions should also be fair. ${ }^{48}$ As Rawls explained, "those who are at the same level of talent and ability, and have the same willingness to use them, should have the same prospects of success." 49 He thus concluded:

[F]ree market arrangements must be set within a framework of political and legal institutions which ... preserves the social conditions necessary for fair equality of opportunity". 50

While Rawls mainly focused on inequalities of opportunity relating to socio-economic class,${ }^{51}$ his ideas can be equally extended to problems of gender-related inequalities of opportunity as well. Indeed Rawls himself noted that his work would be "seriously defective" if it did not articulate the political values essential to justify the institutions needed to secure the equality of women. ${ }^{52}$

Applying Rawls' second principle of justice, we see then that women on boards initiatives are justifiable in that they promote a more equal, and therefore just, society by seeking to correct gender-related inequalities of opportunity. At the same time, however, applying Rawls' work to existing women on boards initiatives also highlights their shortcomings.

Rawls argued that positions should not only be formally open to all, but that equally skilled, willing, and able individuals be given the same prospects of success by preserving the social conditions necessary for fair equality of opportunity. Conversely, while the government has ensured formal opportunities for women by prohibiting legal discrimination

\footnotetext{
${ }^{47}$ Rawls (n 45) 42; Rawls (n 44) 53.

${ }^{48}$ Rawls (n 45) 63.

49 ibid.

50 ibid.

${ }^{51}$ Rawls did not consider sex-related differences in his work because he focused on ideal theory. Rawls (n 45) 65.

52 ibid 66.
} 
on the basis of gender, ${ }^{53}$ it has not similarly ensured that the conditions necessary for women's fair equality of opportunity have been preserved.

Indeed, the systematic under-representation of women at the board level is a signal that social and institutional arrangements - the conditions necessary to preserve fair equality of opportunity for women in business - are deficient. In particular, the unequal division of family labour - requiring women to balance professional and domestic responsibilities ${ }^{54}$ and an inflexible job model, which demands unfailing availability and a break-free linear career path, ${ }^{55}$ have both been found to affect women's abilities to participate in senior business positions. ${ }^{56}$ Yet the government's initiatives do not address either of these factors.

In fact, the need to ensure the social conditions necessary for fair equality of opportunity is one of the most important reasons for developing an equality rationale for initiatives to promote women on boards. By looking only to an economic rationale, the organizational and institutional changes needed to achieve greater representation of women on boards in a sustainable manner are likely to be overlooked. Without such changes, increasing the number of women on boards will be achieved only in a limiting manner, in that the structural conditions that have impeded women's fair equality of opportunity are unlikely to be addressed. In other words, the government's current initiatives may address the symptoms but not the root causes of a deeper problem. While it is understandable that rules amending board structure are not an appropriate vehicle for promoting social change, it is nevertheless crucial to develop a thorough understanding of the underlying issues of the

\footnotetext{
${ }^{53}$ See Sex Discrimination Act 1975; Equality Act 2010.

${ }^{54}$ Georges Desvaux et al., Women Matter: Gender Diversity, A Corporate Performance Driver (McKinsey and Co., 2007) $10<\mathrm{http} / / / \mathrm{www}$.europeanpwn.net/files/mckinsey_2007_gender_matters.pdf> accessed 2 Oct 2013.

${ }_{55}$ Martin Kornberger et al., 'Changing Gender Domination in a Big Four Accounting Firm: Flexibility, Performance and Client Service in Practice' (2010) 35(8) Accounting, Organizations and Society 775, 788-89; Louise Ashley and Laura Empson, 'Convenient Fictions and Inconvenient Truths: The Role Of Paradox In Understanding Female Career Progression Within Leading U.K. Accountancy Firms'(2012) Cass Centre for Professional Service Firms - Working Paper CPSF-008 <http://www.cass.city.ac.uk/_data/assets/pdf_file/0011/130133/working-paper-008.pdf> accessed 2 October 2013.

${ }^{56}$ For a more in-depth discussion of these factors see Part 4(B)(ii)(b), below.
} 
specific problem which are being addressed. This is precisely what an equality rationale can provide.

Finally, an equality rationale also offers a distinctive advantage that an economic only rationale cannot offer. Because equality is a "human right based in moral legitimacy", it is an inalienable right. ${ }^{57}$ Thus, justifying initiatives that promote gender diversity on boards in equality is not dependent on women's effects on firm financial performance. That is, even if a correlation cannot be found between women on boards and shareholder maximization, an equality rationale still justifies measures to promote women on boards. In this light, an equality rationale can be seen as emphasising women's rights - as opposed to business reform - as the focus of the government's measures. In short, increased female representation on boards is valued in its own right.

\section{B. A Rebolstered Economic Rationale}

While an equality rationale is perhaps the most important justification for initiatives promoting gender diversity on boards, economic rationales remain key supplements to the equality rationale. In particular, economic rationales may be able to convince ardent sceptics or "convert power holders to the cause", 58

An economic rationale is in truth a utilitarian argument for measures that increase the number of women on boards. It is the use of or the consequences that women can bring that is underscored. ${ }^{59}$ For instance, the utility of increased representation of women is generally thought of in terms of resources and interests. ${ }^{60}$ Under a resource argument, women are

\footnotetext{
${ }^{57}$ Noon (n 25) 781.

${ }^{58}$ Marian Sawer, 'Representation of women: Questions of accountability'(2000) Paper for IPSA Conference, 2 $<$ http://ipsarc19.anu.edu.au/papers/Sawer.pdf> accessed 2 October 2013.

${ }^{59}$ Teigen (n 41) 64.

${ }^{60}$ Bjørkhaug and Sørensen (n 43) 189; Helga M. Hernes, Welfare State And Woman Power: Essays In State Feminism (Norwegian University Press 1987), 22-25
} 
thought to be able to contribute experience and competence not equally available from men, meaning that a failure to utilize women is thought of as wasting resources. ${ }^{61}$ Conversely, under an interest argument, women are thought of as representing (or better representing than men) women's interests. ${ }^{62}$

Interestingly, Lord Davies' report is almost wholly rationalized in terms of the classic utility arguments for increased representation of women. Three of the arguments he puts forward for justifying his recommendations - improved performance, accessing the widest talent pool, and being more responsive to the market - discuss women's contributions to boards in terms of their experience, perspective and interests. ${ }^{63}$

Yet despite the utilitarian rationales proffered in Lord Davies' report, the report fails to detail concrete links between women's contributions and benefits to companies. For instance, the report notes that female directors enhance board independence and "ask the awkward questions more often". From these contributions the report assumes better decisionmaking and speculates that decision outcomes are "likely to be better". ${ }^{4}$ However, it fails to show how board independence or asking awkward question actually improves decisionmaking.

As the premise of the economic or utilitarian rationale is the consequences of women's participation, it becomes imperative under this rationale to demonstrate the benefits women can bring to companies. Since benefits for firms usually mean wealth maximisation, ${ }^{65}$ women's contributions would ideally, under this rationale, be defined in terms of their effects on firm performance. Nevertheless, despite countless studies examining this relationship, researchers have not been able to locate a consistent and robust relationship between these

\footnotetext{
${ }^{61}$ See also Bjørkhaug and Sørensen (n 43) 189; Teigen (n 41) 66.

${ }^{62}$ Bjørkhaug and Sørensen (n 43) 189; Anne Phillips, The Politics of Presence (OUP, 1995).

${ }^{63}$ Lord Davies (n 1) 8-10.

${ }^{64}$ ibid 8.

${ }^{65}$ Company Law Review Steering Group (n 6) para. 5.1.12.
} 
two. ${ }^{66}$ As such relationships have been difficult to ascertain - and indeed may never be possible to definitively locate ${ }^{67}$ - another proxy for firm's economic interests must be identified. One alternative is to focus on board effectiveness.

\section{i. $\quad$ Focus on Board Effectiveness}

The notion of board effectiveness draws from a rich line of literature stemming from strategic management theory. Strategic management theorists argue that boards should not be seen as compositions of individuals, but rather as groups of decision-makers. Consequently, examining the contributions of boards should focus, not on their demography, but rather on their processes or the way in which boards make their decisions.

In fact, strategic management theorists have found that demography does not have a direct relationship to firm performance, but rather influences firm performance in a complex and indirect manner. ${ }^{68}$ In part, this is because boards operate as episodic decision-makers, which are largely not involved in implementation. Instead, they find that the output produced by boards is mainly "cognitive in nature" ${ }^{69}$ Scholars have therefore concluded that

\footnotetext{
${ }^{66}$ Deborah L. Rhode and Amanda K. Packel, 'Diversity on Corporate Boards: How Much Difference Does Difference Make?' (2010) Rock Center for Corporate Governance, Stanford University - Working Paper No. 89 $<$ http://papers.ssrn.com/sol3/papers.cfm?abstract_id=1685615> accessed 2 October 2013 (surveying two dozen studies and concluding that a consistent positive or negative relationship between these two variables cannot be found).

${ }^{67}$ Benjamin E. Hermalin and Michael S. Weisbach, ' Boards of Directors as an Endogenously Determined Institution: A Survey of Economic Literature’ (2003) Econ. Policy Rev. 1; Rose (n 33); Dale-Olsen et al. (n 7); Dalton et al. (n. 35).

${ }^{68}$ Daniel P. Forbes and Frances J. Milliken, 'Cognition and corporate governance: Understanding Boards of Directors as Strategic Decision Making Groups' (1999) 24 Acad. of Management Rev. 489, 490. As Zahra and Pearce argue, board attributes influence board roles. The effect of boards on company performance, however, is indirect. By performing their service and control roles, directors shape managerial strategic choices or actions resulting in strategic outcomes. It is these strategic outcomes then, which affect financial performance. See Shaker A. Zahra and John A. Pearce II, 'Boards of Directors and Corporate Financial Performance: A Review and Integrative Model' (1989) 15:2 J. of Management 291, 296-7.

${ }^{69}$ Because boards are "responsible only for monitoring and influencing strategy — not for implementing strategic decisions or for day-to-day administration", their role is cognitive: Forbes and Milliken (n 68) 492.
} 
demographic variables of board members only directly influence how effectively boards perform their tasks, while a board's overall effectiveness affects firm performance. ${ }^{70}$

Strategic management theory therefore suggests one reason why the relationship between gender diversity on boards and firm performance is mixed. As women's contributions to firm performance are made through an intervening variable, board process, it becomes considerably more difficult to extract and measure their particular contribution to firm performance. ${ }^{71}$ Nevertheless, strategic management theory also provides a framework through which women's contributions as directors can be assessed. In short, if women positively contribute to the process by which boards make their decisions - which in turn makes the board more effective and increases firm performance - a rebolstered economic rationale for gender diversity on boards will have been found.

\section{ii. The Model for Effective Boards}

Before examining women's contributions to board effectiveness, it is useful to examine the model of board effectiveness. Strategic management theorists posit that effective boards are a function of two criteria, which, in turn, are influenced by three board processes. The two criteria are effective board task performance and the ability to work together in a cohesive manner. ${ }^{72}$ In turn, these criteria for effectiveness are influenced by three board processes: effort norms; cognitive conflict; and the board's use of its knowledge and skills. ${ }^{73}$ Figure 1 pictorial depicts this model. While strategic management theorists have departed from an

\footnotetext{
${ }^{70}$ Board task performance directly affects firm performance, while board cohesiveness affects how well boards perform their tasks and therefore contributes indirectly to firm performance. See Forbes and Milliken (n 68) 492.

${ }^{71}$ Researchers argue that because of the multiple intervening processes between board structure and firm performance it is difficult to assess the precise relationship between the two. Indeed, varying results of measurements of this relationship may be due to "methodological and conceptual issues, such as lack of attention to group dynamics, high complexity of processes, variations in measurements of board attributes and performance". See David Wan and C. H. Ong, 'Board Structure, Process and Performance: Evidence from Public-listed Companies in Singapore'(2005) 13:2 C.G. 277, 278.

${ }^{72}$ Forbes and Milliken (n 68) 492.

${ }^{73}$ ibid. See also Wan and Ong (n 71) 278.
} 
analysis of demographic effects on firm performance, they are quick to point out that although the criteria for board effectiveness are distinct from firm performance, they both, directly or indirectly, contribute to firm performance. ${ }^{74}$

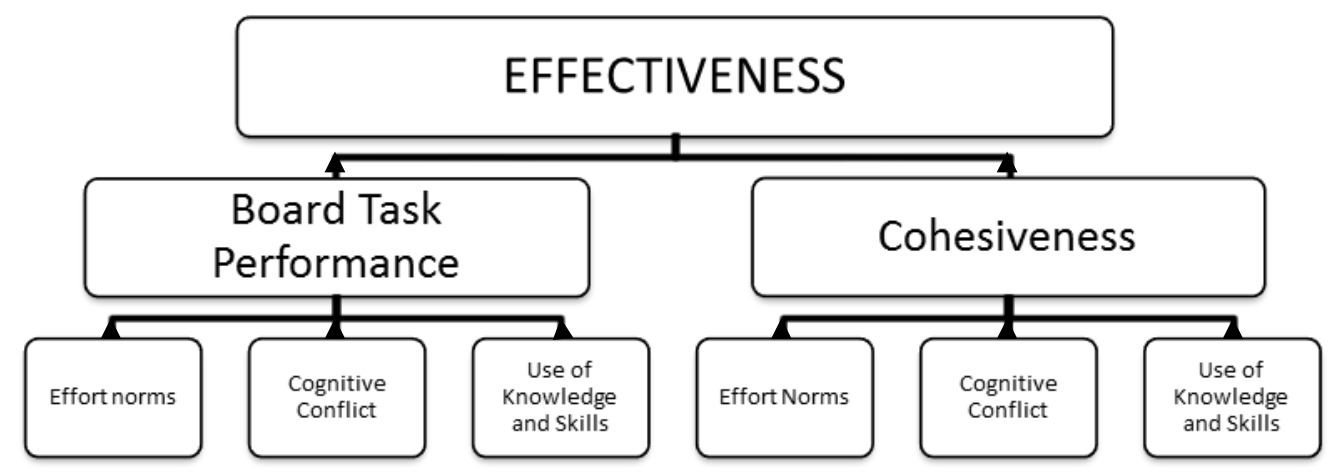

Figure 1: Model of Board Effectiveness

The first criterion for an effective board is board task performance. This represents the board's effectiveness in the three broad functions of a board: service, management, and control. ${ }^{75}$ Service tasks are those services that the board can offer to top management such as providing access to networks or establishing contacts with the external environment and providing counsel and advice to executives. ${ }^{76}$ Management tasks include the exercise of managerial functions reserved to the board such as broad policy making, the hiring of top management, or the setting of executive pay. ${ }^{77}$ Finally, the most important task of boards is control, or the reduction of the agency costs perpetuated by management acting as agents of shareholders. Although control tasks broadly refer to the board's monitoring of management's activities, it can further be broken down into operational control, or the ex-

\footnotetext{
${ }^{74}$ Forbes and Milliken (n 68) 492.

${ }^{75}$ Stephen M. Bainbridge, Corporate Governance after the Financial Crisis (OUP 2012) 44.

${ }^{76}$ Bainbridge (n 75) 49; Zahra and Pearce (n 68) 292.

${ }^{77}$ Bainbridge (n 75) 46.
} 
post monitoring of financial-oriented managerial decisions, and strategic control, or the exante control of management's long term and qualitative oriented decisions. ${ }^{78}$

Second, board effectiveness is dependent on board cohesiveness. This is the degree to which board members favour each other. In short, the more cohesive the board, the more they are committed to the group. ${ }^{79}$

Strategic management theorists further argue that the effectiveness of boards is influenced by the processes through which they make their decisions. Thus, effort norms, or the group's shared belief regarding the level of effort each individual is expected to put toward a task, is one of the three recognised process factors that influence board task performance. ${ }^{80}$ Effort norms can have a significant influence on individual behaviour by encouraging each director to "do their homework" before meetings, to engage in firmspecific diligent research, or even to 'use pocket calculators' during board meetings. ${ }^{81}$

Second, board effectiveness is influenced by cognitive conflict. ${ }^{82}$ This relates to disagreements about the content of the tasks being performed, including differences in viewpoints, ideas, and opinions. ${ }^{83}$ Cognitive conflict involves the use of critical and investigative interaction processes that can enhance the board's performance of its control function and can result in the consideration of more alternatives and the more careful evaluation of alternatives. ${ }^{84}$ Multiple viewpoints, the exchange of positive and negative comments, and solution diversity are thought to enhance decision-making. ${ }^{85}$

\footnotetext{
${ }^{78}$ Forbes and Milliken (n 68) 492; Sabina Nielsen and Morten Huse, 'The Contribution of Women on Boards of Directors: Going beyond the Surface' (2010) 18(2) C.G.136, 137.

${ }^{79}$ Irvin Summers et al. 'Work-group Cohesion' (1988) 63:2 Psychological Rep. 627; Stephen J. Zaccaro and Gregory H. Dobbins, 'Contrasting Group and Organizational Commitment: Evidence For Differences Among Multilevel Attachments' (1989) 10 J. of Org. Behavior 267, 271.

${ }^{80}$ Ruth Wageman, 'Interdependence and Group Effectiveness' (1995) 40 Admin. Science Q. 145, 150; Forbes and Milliken (n 68) 492.

${ }^{81}$ Forbes and Milliken (n 68) 494.

${ }^{82}$ ibid 494.

${ }^{83}$ Karen A. Jehn, 'A Multimethod Examination of the Benefits and Detriments of Intragroup Conflict' (1995) 40 Admin. Science Q. 256, 258.

${ }^{84}$ Forbes and Milliken (n 68) 494.

${ }^{85}$ ibid.
} 
Finally, board effectiveness is influenced both by the degree of specialized knowledge and skills that boards possess and their ability to utilise their knowledge and skills and apply them to tasks. ${ }^{86}$ Effective boards are thus able to integrate individual expertise and apply them to firm specific issues. They will also elicit and respect each other's expertise, build upon each other's contributions and seek to combine their insights in creative, synergistic ways. $^{87}$

Moreover, there is a relationship between the two criteria of board effectiveness. Since board task performance requires communication and deliberation, board members must exhibit a minimum level of interpersonal attraction, or cohesiveness, in order to engage in these actions. ${ }^{88}$ Cohesiveness also fosters trust of each other's judgment and expertise and can enhance decision-making by promoting earlier and more extensive decision-making. ${ }^{89}$

At the same time, too much cohesiveness can lead to group think, wherein independent critical thinking is replaced by striving for unanimity among members, or a proliferation of excessive personal exchanges. ${ }^{90}$ Nevertheless, strategic management theorists have found that so long as cognitive conflict is present among members, even high levels of cohesiveness will not detract from the effectiveness of decision-making. ${ }^{91}$

\section{iii. Women's Contributions to Effective Boards}

Having explored the key attributes of an effective board and its process, this section examines the contributions women have been found to make to each of the facets of board effectiveness

\footnotetext{
${ }^{86}$ ibid 495.

${ }^{87}$ ibid 496

88 ibid.

${ }^{89}$ ibid.

${ }^{90}$ See generally Irving L. Janis, Victims of Groupthink: A Psychological Study of Foreign-Policy Decisions and Fiascos. (Houghton-Mifflin, 1972).

${ }^{91}$ Forbes and Milliken (n 68) 496.
} 
and the elements of board process. The discussion thus focuses on the role female directors play in each of the constitutive elements of board effectiveness.

The discussion begins by examining the contributions of female directors on process variables before turning to their impact on the criteria for board effectiveness. In effect, it moves from a macro perspective on women's influence on boards, by broadly examining how they contribute to process, before turning to a micro perspective by specifically looking at their impact on particular tasks.

Nevertheless, a word of caution must be offered: women's contributions explored in this section are generalizations drawn from robust empirical studies that have examined the actions or qualities of either women on boards or women in senior management positions. Consequently, any one woman may make only some or even none of these contributions. Still, the studies of women's contributions are useful in making general assessments of women's contributions to the board process.

\section{a) Women's Contributions to Board Process}

Board process involves three attributes of boards: effort norms, cognitive conflict, and possession and use of knowledge and skills. As the discussion will evidence, women make unique contributions to each of these process variables.

\section{(1) Effort Norms}

Effort norms are the expected standard of intensity that each board member will apply to task-performance behaviour. ${ }^{92}$ These norms dictate the expected level of preparation for and

${ }^{92}$ ibid. 
participation in board meetings that each board member should exhibit. Effective boards have been found, for instance, to have board members that review information essential for board decisions prior to meetings; to have meetings in which issues are discussed in sufficient depth, to document meetings by way of minutes, and to review the performance of the board..$^{93}$

Studies have concluded that women contribute to effort norms in a number of ways. For instance, women have been found to bring higher expectations of board member responsibility due to their having surmounted additional hurdles in obtaining their position; ${ }^{94}$ to spend more time preparing for board meetings, trying to understand the nature and logic of board work, and devoting time to board evaluation; ${ }^{95}$ and to have better attendance records for board meetings than men. ${ }^{96}$ In addition, the presence of women on boards improves the attendance behaviour of male counterparts and induces men's preparation time for meetings. ${ }^{97}$ Studies have further shown that female directors have a significant positive effect on board development activities relating to board instructions and board evaluation, ${ }^{98}$ and that women make boards more active. ${ }^{99}$ Women's extensive preparation for board meetings has also enabled them to raise conflict-inducing or "tough" issues. ${ }^{100}$

\section{(2) Cognitive Conflict}

\footnotetext{
${ }^{93}$ Nielsen and Huse (n 78) 139.

${ }^{94}$ Nancy Fondas and Susan Sassalos 'A Different Voice In The Boardroom: How the Presence of Women Directors Affects Board Influence Over Management' (2000) 12:2 Global Focus 13.

${ }^{95}$ Morten Huse and Anne G. Solberg, 'Gender-related boardroom dynamics: How Scandinavian women make and can make contributions on corporate boards' (2006) 21:2 Women In Management Rev. 113.

${ }^{96}$ Adams and Ferreira (n 7) 296, 298.

${ }^{97}$ ibid; Huse and Solberg (n 95) 13. Not wanting women to catch them "asleep" has prompted some male directors to improve their preparations for meetings. ibid.

${ }^{98}$ Nielsen and Huse (n 78) 140.

${ }^{99}$ Daniel Ferreira, 'Board Diversity' in H. Kent Baker and Ronald Anderson (eds.) Corporate Governance: A Synthesis of Theory, Research, and Practice (John Wiley and Sons 2010) 233; Schwartz-Ziv (n 7) 17.

${ }^{100}$ Nancy McIrnerney-Lacombe et al., 'Championing the Discussion of Tough Issues: How Women Corporate Directors Contribute to Board Deliberations' in Susan Vinnicombe et al. (eds.) Women on Corporate Boards Of Directors: International Research and Practice (Edward Elgar Publishing 2008) 127.
} 
Women have been found to make significant contributions to open discussions of task-related differences. Studies have documented that female board members bring diverse viewpoints to the board room and encourage greater discussions and arguments over board decisions. ${ }^{101}$ Women also favour a democratic and participative style of decision-making and are more prone to ask questions. ${ }^{102}$ Female directors have further been found to foster boardroom discussions because of their transformational leadership style which preferences collaboration, sharing of resources and flexibility. This style tends to favour listening to other points of view and consideration of interests other than their own and can improve communication among directors and between board and management. ${ }^{103}$ At the same time, they are able to champion difficult or controversial issues that their male colleagues may avoid in board discussions, ${ }^{104}$ broaden discussions to better represent the concerns of a variety of stakeholders, ${ }^{105}$ and when they have divergent views, express and actively engage discussion of these views. ${ }^{106}$ Moreover, women's contributions to board discussions tend to be based on facts and details - which they often demand - while men "tend to shoot from the hip". ${ }^{107}$ Studies have also documented that women can contribute to the creativity or innovativeness of board discussions and of solutions considered in the board meetings. ${ }^{108}$

\footnotetext{
${ }^{101}$ Vicki W. Kramer et al., 'Critical Mass on Corporate Boards: Why Three or More Women Enhance Governance' (2006) Wellesley Center for Women - Report No. 74; Huse and Solberg (n 95).

${ }^{102}$ Huse and Solberg (n 95) 9-10; Kramer et al. (n 101) 224

${ }^{103}$ Diana Bilimoria, 'Building the Business Case for Women Corporate Directors' in Ronald J. Burke et al. (eds.), Women on Corporate Boards of Directors: International Challenges and Opportunities, (Kluwer Academic Publishers 2000) 31; Kramer et al. (n 101) 224.

${ }^{104}$ See generally McIrnerney-Lacombe et al. (n 100) 123.

105 Kramer et al. (n 101) 224.

${ }^{106}$ See generally Beate Elstad and Gro Ladegard, 'Women on corporate boards: key influencers or tokens?' (2010) 16:4 J. of Management and Governance 595.

${ }^{107}$ Kate Sweetman, 'How Women Have Changed Norway's Boardrooms' (Harvard Business Review Blog, 27 July 2009) <http://blogs.hbr.org/hbr/hbr-now/2009/07/how-women-have-changed-norways.html> accessed 2 October 2013. See also Kramer et al. (n 101).

108 Toyah Miller and Maria del Carmen Triana, 'Demographic Diversity in the Boardroom: Mediators of the Board Diversity-Firm Performance Relationship' (2009) 46:5 J. of Management Studies 755, 775; M. Huse et al., 'Women and Employee-Elected Board Members and their Contributions to Board Control Tasks' (2009) 89(4) J. of Bus. Ethics 581.
} 


\section{(3) Possession and Use of Knowledge and Skills}

A 2008 study of newly appointed directors of FTSE 100 firms in the U.K. has found that female directors are more likely to have MBA degrees, international experience and more experience as small firm board directors, although less CEO/COO experience, than their male counterparts. ${ }^{109}$ Female directors are also more likely to possess expert backgrounds outside of traditional business ${ }^{110}$ and have on average higher formal education than their male counterparts. ${ }^{111}$ In addition, female directors often possess unique skill sets not possessed by men. For example, studies have documented women's greater familiarity with consumer products $^{112}$ or their greater empathy towards stakeholder issues. ${ }^{113}$ Women have further been found to possess greater influence over a community than men ${ }^{114}$ and may have a greater inclination to reduce risks. ${ }^{115}$ In addition, studies have shown that female directors who have worked their way up from male dominated cultures of senior management exhibit persistence and resilience or skills which enable them to champion difficult issues. ${ }^{116}$

Nevertheless, studies have also found that some women directors are reluctant to use their unique skill set, in part because they are consciously trying to avoid stereotypes. ${ }^{117}$

\footnotetext{
${ }^{109}$ Val Singh et al., 'Newly Appointed Directors in the Boardroom: How Do Women and Men Differ?' (2008) 26(1) European Management J. 48.

${ }^{110}$ Amy J. Hillman et al, 'Women and Racial Minorities in the Boardroom: How Do Directors Differ?'(2002) 28

J. of Management 747.

${ }^{111}$ Frederik Engelstad, 'Limits to State Intervention into the Private Sector Economy' in Engelstad and Teigen (n. 7) 255.

112 Desvaux et al. (n 54) 10.

${ }^{113}$ Heather Foust-Cummings, 'Women on Corporate Boards of Directors: Best Practice Companies' in Vinnicombe et al. (n 100) 214; Kramer et al. (n 101).

${ }^{114}$ Hillman et al. (n 110); Siri Terjesen et al., 'Do Women Still Lack the 'Right' Kind of Human Capital for Directorships?' in Vinnicombe et al. (n 100) 159.

${ }^{115}$ Corinne Post et al., 'Green Governance: Boards of Directors' Composition and Environmental Corporate Social Responsibility' (2011) 50(1) Bus. and Society 189, 195; Farrell and Hersch (n 7). However, converse results have also been found. See Allan N. Berger et al., 'Executive Board Composition and Bank Risk Taking', (2012) Discussion Paper - Deutsche Bundesbank No 03/201; Renee B. Adams and Patricia Funk, 'Beyond the Glass Ceiling: Does Gender Matter?' (2012) 58:2 Management Science 219.

${ }^{116}$ McIrnerney-Lacombe et al. (n 100) above.

${ }^{117}$ Patricia Bradshaw and David Wicks, 'The Experiences of White Women on Corporate Boards in Canada: Compliance and Non-compliance to Hegemonic Masculinity' in Burke et al. (n 103) 201; Morten Huse, 'Women directors and the "Black Box" of Board Behavior' in Vinnicombe et al. (n 100) 145.
} 
Thus, where women either do not possess different skills and knowledge from men, because their professional backgrounds are very similar or because they refrain from behaviour that differentiates them from their male colleagues, women's contributions to board effectiveness may be limited. At the same time, having a critical mass of women ${ }^{118}$ or having a balanced board ${ }^{119}$ often reduces these types of problems. ${ }^{120}$

\section{b) Women's Impact on Board Effectiveness Criteria}

Having explored women's contributions to board process, this section examines women's specific contributions to board tasks and cohesiveness.

\section{(1) Board Tasks}

As mentioned previously, board tasks can be broadly divided into service, management, and control tasks. However, carrying out control tasks is widely thought to be the most important function of boards, and these tasks can be further broken down into strategic control and operational control tasks. ${ }^{121}$ Strategic tasks usually refer to those that pertain to the board's own initiatives in developing a firm. This can include decision-making related to major resource allocation and assessments of resources, products, and markets. Strategic tasks may also relate to decision-making pertaining to corporate social responsibility and stakeholder expectations. ${ }^{122}$

\footnotetext{
${ }^{118}$ A critical mass is thought to be reached when there are at least 3 women on a board. See Kramer et al. (n 101) 224; Desvaux et al. (n 54) 12; Schwartz-Ziv (n 7) 3; Allison M. Konrad et al., 'Critical mass: The Impact of Three or More Women on Corporate Boards' (2008) 37(2) Organizational Dynamics 145.

${ }^{119}$ Luis Rodriguez-Dominguez et al, 'Explanatory factors of the relationship between gender diversity and corporate performance' (2012) 33:3 European J. of L. and Econ. 603, 617 (arguing for more than 50 percent of women on boards).

${ }^{120}$ See, e.g., McIrnerney-Lacombe et al. (n 100); Konrad et al. (n 118); Elstad and Ladegard (n 106).

${ }^{121}$ Nielsen and Huse (n 78) 137.

$122 \mathrm{ibid}$
} 
Studies have documented that women generally exert a positive impact on these types of tasks, particularly tasks of a qualitative nature. ${ }^{123}$ For instance, women's leadership style, which involves being inclusive and sharing power and information with colleagues, has been found to foster strategy development. ${ }^{124}$ They have also been found to contribute to corporate social responsibility related issues and their improvement. Thus, research demonstrates a positive correlation between the number of female directors or the percentage of women on the board and a company's dedication to corporate social responsibility initiatives. ${ }^{125}$

Conversely, operational tasks generally pertain to financial control of the business and may include behaviour control such as evaluations of the performance and compensation of the CEO and top management team. In this area, women have been found to be highly effective monitors of management. ${ }^{126}$ It is surmised that this is a result of women's broader range of professional experience and inclination to possess advanced degrees. Moreover, this may be because women, if appointed to boards, are more likely to be appointed to audit, nominating and corporate governance committees. ${ }^{127}$ In fact, Adams and Ferreira conclude that female directors, overall, are tougher monitors than their male counterparts. Their research finds that boards with more female directors are more likely to hold CEOs accountable for poor stock performance, ${ }^{128}$ suggesting that female directors on boards are more likely to correlate with higher CEO turnover. At the same time, they find that this

\footnotetext{
${ }^{123}$ See, e.g. Huse et al.(n 108).

124 ibid.

${ }^{125}$ Richard A. Bernardi et al., 'Does Female Representation on Boards of Directors Associate With Fortune's “100 Best Companies to Work For” List?' (2006) 45(2) Business and Society 235; Stephen Bear et al., 'The Impact of Board Diversity and Gender Composition on Corporate Social Responsibility and Firm Reputation' (2010) 97 J. of Business Ethics 207.

${ }^{126}$ Hillman et al. (n 110); Amy J. Hillman and Thomas Dalziel, 'Board of directors and firm performance: integrating agency and resource dependence perspectives’ (2003) 28 Acad. of Management Rev. 383; Adams and Ferreira (n 7); Huse et al. (n 108).

${ }^{127}$ Adams and Ferreira (n 7) 300. These findings are confirmed in M. Schwartz-Ziv (n 7) 30.

128 ibid 301.
} 
toughness in monitoring can lead to overmonitoring for already well-governed firms, but be beneficial to firms with weak governance. ${ }^{129}$

Interestingly, female directors appear to have no impact on CEO compensation. One reason for this is because they are less likely to be appointed to compensation committees. ${ }^{130}$ However, commentators have also posited that board members who are demographically similar to CEOs are more likely to support them and accordingly award them higher compensation. ${ }^{131}$ Under this rationale, then, increased female representation on boards may have an effect on lowering CEO compensation.

\section{(2) Cohesiveness}

Finally, as board effectiveness is in part dependent on cohesiveness, women's contribution to this factor must also be considered. Studies have found that demographic diversity in groups in many cases can lead to conflict. ${ }^{132}$ This is not the aforementioned - and desirable cognitive conflict, or disagreement about the task at hand, but rather relational conflict personal disagreements - which can detract from the cohesiveness of the board. However, because of evidence of women's participative leadership behaviour and greater sensitivity towards others, they may be more inclined to be accepting of other people's positions. Indeed, one study of female directors in Norway has found that the ratio of women directors is negatively associated with board conflict, suggesting that women's presence on the board is not disruptive but can, in fact, contribute to cohesiveness. ${ }^{133}$

\footnotetext{
${ }^{129}$ ibid. Despite this finding, however, Adams and Ferreira caution against drawing any causality inferences between female directors and firm performance as they observe that causality is too difficult to ascertain with certainty.

130 ibid 300-301.

${ }^{131}$ James D.Westphal and Edward J. Zajac, 'Who Shall Govern? CEO/Board Power, Demographic Similarity, and New Director Selection’ (1995) 40(1) Admin. Science Q. 60.

${ }^{132}$ Frances J. Milliken and Luis L. Martins, 'Searching For Common Threads: Understanding the Multiple Effects of Diversity in Organizational Groups' (1996) 21(2) Acad. of Management Rev. 402, 403.

${ }^{133}$ Nielsen and Huse (n 78) 142, 145.
} 
Nevertheless, there is some risk that female directors may be too accommodating of the ideas of other board members or unable to present and bring in their alternative knowledge and experience which would give rise to relational conflict. ${ }^{134}$ While these attributes help foster board cohesiveness, they can detract from increased cognitive conflict. Thus, in order to capture the unique contributions of female directors, women must be able to assert their idiosyncratic knowledge and experience, which fosters cognitive conflict, without allowing these idiosyncrasies from becoming the source of relational conflicts. However, the need for female directors' to balance these competing aims is lessened if the remaining board members are also open to multiple viewpoints and opinions. ${ }^{135}$

\section{iv. The Rebolstered Economic Rationale}

Examining women's contributions to board effectiveness thus reveals that women can make several unique benefits to board operations, which positively affects firm performance. They can improve board development work, incentivise preparation for and attendance at meetings and generally improve overall board activity. In addition, they can proffer unique and different perspectives and/or alternate knowledge and skill sets that can diversify board discussions and the decisions taken. These contributions to the process of board decisionmaking can, in turn, result in superior performance of qualitative board tasks, monitoring of management, strategy development and engagement in stakeholder issues. Women's presence can also make boards more cohesive groups which can improve board commitment to the business and improve their overall decision-making.

At the same time, companies may not need all of women's unique contributions to board decision-making. Thus, firms that do not require strengths in areas where women have

\footnotetext{
134 ibid; Huse et al. (n 108) 592-593.

135 See generally Nielsen and Huse (n 78).
} 
been found to make particular contributions to boards, such as qualitative decision-making or monitoring, may not necessarily be able to translate every contribution of women to boarddecision making into improved firm performance. In other words, some of the contributions of women to boards may be firm specific. Moreover, examining women's contributions to board effectiveness reveals that simply placing a woman on a board does not automatically translate into the contributions women have been known to make to boards. Women whose backgrounds are very similar to their male contemporaries, those that easily conform to the ideas espoused by other board members, or those that are unable to present and use their alternate views, experience or knowledge may not make unique contributions to board decision-making.

At first glance, the failure to demonstrate that every contribution of any woman appointed to a board will improve decision-making may suggest that an economic rationale for women on boards, underpinned by board effectiveness, is not as unequivocal as the traditional "business case" for gender diversity on boards. However, board effectiveness as the measure of women's contributions to boards offers two advantages. First, it demonstrates that women as a group make several distinct contributions to board effectiveness, including improving overall board activity, representing women's interests, and increasing board cohesiveness, all of which, in turn, improves firm performance. Thus, generally speaking, focusing on board effectiveness demonstrates that women, unequivocally, improve firm performance, albeit indirectly. In other words, women's contributions to board effectiveness generally evidence the economic rationale for increasing women on boards.

Second, focusing on board effectiveness reveals both the specific advantages and disadvantages that women can make to boards. Implicit in this recognition is that any demographic variable, including male, white and fifty-something - the typical characteristics 
of directors ${ }^{136}$ - likely offer some advantages and some disadvantages to board decisionmaking. Indeed, the research on women's contributions to boards has already highlighted some of male directors' shortcomings despite men not being the focus of the research. Focusing on board effectiveness therefore highlights the importance of having roughly balanced boards of men and women in order to ensure that gender-specific disadvantages that directors can make to the board decision-making process will be offset.

\section{Increasing Women on Boards: The Way Forward}

Given both the equality and economic justifications for increasing the number of women on boards, the next step is to examine how best to effect this aim. A common approach to fostering women on boards has become to impose gender quotas. While several countries have already adopted this approach, Norway was the first to do so and has been one of the most successful models for use of the quota system.

The U.K. government has, until now, eschewed quotas. Instead it has generally supported companies' self-regulation in the area. Nonetheless, the threat of quotas persists in this area as both the U.K. government and the European Commission have indicated an interest in imposing quotas if efforts to self-regulate do not effect substantive changes. ${ }^{137}$ In determining the best way forward for fostering women on boards it thus becomes necessary to engage directly with the use of quotas.

The next sections examine first, the merits of quotas, before turning to examine whether quotas would be a suitable tool for effecting change in this area in the U.K. Second, this part moves to discuss alternative approaches for fostering women on boards by examining the issue from both a supply and a demand perspective.

\footnotetext{
${ }^{136}$ Mairi Maclean and Charles Harvey, 'Women on Corporate Boards of Directors: The French Perspective' in Vinnicombe et al. (n 100) 47.

${ }^{137}$ See e.g., Lord Davies (n 1) 2; European Commission (n 3).
} 


\section{A. Quotas}

Given that the U.K.'s government's self-regulatory approach to increasing the number of women on boards has struggled to make substantive changes, the most likely solution to effect a more rapid change would be for the government to impose regulations prescribing quotas. Already, several European countries have adopted this approach, although with varying levels of success. Interestingly countries, such as Spain, that have not accompanied their quota requirements with vigilant sanctions for non-compliance have not achieved greater levels of success than self-regulatory approaches. ${ }^{138}$ Nevertheless, Norway, which imposed both strict requirements for a 40 percent quota for female representation on boards and stringent sanctions for non-compliance, ${ }^{139}$ has within a short amount of time achieved unparalleled success with its initiative.

As the first state to impose quotas for gender diversity on boards, Norway has become an example of the benefits that quotas can offer. No other state can offer comparable information, either due to the recency of their efforts or the incomplete nature of their plan, on the advantages of a quota system. For this reason, in assessing the value of quotas for the U.K., it becomes prudent to examine Norway's approach to see if its system of quotas could be transferable to the U.K.

However, some important differences between Norway and the U.K. suggest that the effectiveness of the quota system in Norway will likely not be able to be replicated in the U.K. For example, gender equality is the prevailing norm in Norway. Indeed, the need to bolster its already prominent international reputation for gender equality was one of the

\footnotetext{
${ }^{138}$ In 2009, women represented only 9 percent on boards despite a 40 percent quota requirement. See Isabel Huerta Viesca, 'Women on the boards of major Spanish corporations after the entry into force of the Organic Equality Law 3/2007' (2010) Co. Law. 219.

${ }^{139}$ Forced dissolution is the ultimate penalty for being in breach of the quota laws. See Mari Teigen, 'Gender Quotas on Corporate Boards' in Engelstad and Teigen (n 7) 124.
} 
reasons the quota laws were introduced in the first place. ${ }^{140}$ Norwegian political tradition has similarly emphasized gender equality, although mainly in the public sector, through measures designed to encourage female employment or to promote work-family reconciliation. Consequently, societal consensus on the importance of gender equality made it much easier for companies to accept and adhere to the quota. Conversely, gender equality as an ideal does not enjoy comparable importance in the U.K. as it does in Norway. ${ }^{141}$

Second, related to the importance of gender equality as a norm in Norwegian society, Norway has a tradition of achieving gender equality by way of quotas. Norwegian political parties have widely used gender quotas since 1974 and since 1981 all public boards, panels and committees require equal representation of both genders. ${ }^{142}$ In fact, most of the other states that have adopted a quota system have a system of using quotas to improve gender parity in their political systems. ${ }^{143}$ In comparison, the U.K. does not employ a quota system for political representation. While both Labour and the Liberal Democrats employ voluntary party quotas, election of political members is not determined through the use of quotas. Thus, the road for quotas in the economy in the U.K. is considerably longer and thornier than in Norway.

Third, Norway's quota requirements apply only to public limited companies, stateand municipality-owned companies and cooperative companies. Thus, only 400 public companies are subject to the quota requirements while the 160,000 private companies are not. ${ }^{144}$ In addition, almost 40 percent of the public companies are dominated by state ownership, meaning that the state was always able to influence the composition of the board

\footnotetext{
140 ibid 122; Bjørkhaug and Sørensen (n 43) 197.

${ }^{141}$ Nicole M. Fortin, 'Gender Role Attitudes and the Labour-market Outcomes of Women across OECD Countries' (2005) 21(3) Oxford Rev. of Econ. Policy 416; Centre for Women \& Democracy, 'Sex and Power 2013: Who runs Britain?' (Centre for Women and Democracy, 2013) < http://www.fawcettsociety.org.uk/wpcontent/uploads/2013/02/Sex-and-Power-2013-FINAL-REPORT.pdf> accessed 2 October 2013.

142 Vibeke Heidenreichat, 'Why Gender Quotas in Company Boards in Norway - and Not in Sweden?' in Engelstad and Teigen (n 7) 154,155; Drude Dahlerup, Women, Quotas and Politics (Routledge 2006).

143 Teigen (n 139) 127-130.

144 ibid 123
} 
in any case. ${ }^{145}$ A comparable law in the U.K. would reach over 10,000 companies, most of which are not dominated by state-ownership, suggesting the much broader reach of comparable legislation in the U.K. than in Norway. ${ }^{146}$

Finally, the success of Norway's initiative is due in part to the stringent sanctions for non-compliance that accompany the quota requirements. Although, companies are warned initially of non-compliance, and then threatened with fines, the ultimate consequence of failing to adhere to the law is forced dissolution. ${ }^{147}$ In fact, several companies re-registered as private companies when they failed to adhere to the quota requirements and were threatened with forced dissolution. ${ }^{148}$ Conversely, failing to adhere to the requirements of appointing directors under the U.K. Companies Act leads only to a fine. ${ }^{149}$ It is therefore unlikely that a quota law in the U.K. will contain sanctions for non-compliance that are stringent enough to induce the same level of compliance as in Norway.

Given the fundamental differences between Norway and U.K., it is unlikely that Norway's success with quotas could be replicated in the U.K. More likely, mandatory quotas would be met with widespread criticism from businesses ${ }^{150}$ in addition to attempts to evade the applicability of the law. The latter could include refusals to adhere to the quota if the sanctions for non-compliance are not strict enough, re-registering as a private company if the rules apply only to public companies, delisting from the relevant stock exchange(s) if the rules pertain only to listed companies, or in extreme situations, incorporating in jurisdictions without quota requirements.

\footnotetext{
${ }^{145}$ Engelstad (n 111) 254.

${ }^{146}$ Dan Prentice, 'The United Kingdom' in Sabrina Bruno and Eugenio Ruggiero (eds.), Public Companies and the Role of Shareholders: National Models towards Global Integration (Kluwer Law International 2011) 197 (citing a 2005 report that there were 11,600 companies registered as plcs in 2004-2005).

147 Teigen (n 139) 124.

${ }^{148}$ Center for Corporate Diversity, 'Center for Corporate Diversity releases new data: The Number of Women Board Directors in Norwegian Companies by June 1, 2007' (Press Release, June 2007) <http://www.corporatediversity.no/pressjune.html> accessed 2 October 2013. Twenty-two companies reregistered from public to private.

${ }^{149}$ Companies Act 2006, s 156(7).

${ }^{150}$ House of Lords - European Union Committee (n 39) 22. The Committee found that many businesses and the government itself were opposed to quotas.
} 
Moreover, in addition to the differences between the two states, studies examining the effects of Norway's gender quotas for boards suggest substantive shortcomings of the legislation itself as well. For example, one study has found that the percentage of women on boards has neither increased above the prescribed amount nor has the number of female chairs increased. ${ }^{151}$ Instead, the study found that the number of women holding multiple directorships has increased. Dubbed the "golden skirts", this small, but select group of women have, as a result of the quota requirements, become a concentrated, powerful and elite group. ${ }^{152}$ Although the authors of the study caution against findings of causality, their research indicates that the quota requirements, even in gender equality friendly Norway, have not made substantive normative changes on this issue. In fact, the problems arising out of the use of quotas is indicative of those foreshadowed by a Norwegian director:

Quotas are an effective tool if you only focus on...statistics...[T]o get more talented female...board candidates, it's all about changing attitudes. This requires long-term efforts. $^{153}$

The next section, consequently, canvasses alternatives to quotas that the U.K. should consider.

\section{B. Alternatives to Quotas}

Given the government's preference for a voluntary approach and as quotas remain problematic in and of themselves, two alternatives to quotas are suggested. The first alternative looks at the issue from a demand perspective by examining methods by which the

\footnotetext{
${ }^{151}$ Cathrine Seierstad and Tore Opsahl, 'For the few not the many? The effects of affirmative action on presence, prominence, and social capital of women directors in Norway' (2011) 27(1) Scandinavian J. of Management 44, 50.

152ibid 51; Anne Sweigart , 'Women on Board for Change: The Norway Model of Boardroom Quotas as a Tool For Progress in the United States and Canada' (2012) 32 Northwestern J. of International L. and Bus. 81A, 84A. ${ }^{153}$ Bjørkhaug and Sørensen (n 43) 197 citing Sigrun Vageng, Executive Director of the Confederation of Norwegian Enterprises.
} 
demand for women as board members can be increased. Drawing from the practices of the American National Football League ("NFL"), it discusses a system through which the NFL increased the number of minority head coaches. The second alternative turns to look at the issue from a supply perspective and discusses both a proposed database for tracking qualified women as well as necessary support mechanisms.

\section{i. Increasing Demand: Lessons from American Football}

\section{a) The Rooney Rule}

In 2002, the NFL noticed that although a significant percentage of African-Americans were professional football players, less than six percent of NFL teams were coached by AfricanAmericans. Determined to increase the number of minority coaches, the NFL introduced a series of recommendations designed to promote diversity in the league. ${ }^{154}$ Included in these recommendations was a rule which mandated that teams seeking to hire a head coach interview one or more minority applicants for the position. After the recommendations were implemented, the rule became known as the "Rooney Rule" after Dan Rooney, owner of one of the teams and chair of the committee making the recommendations. ${ }^{155}$ The Rooney Rule is thought to have increased the number of minority head coaches from 6 to 22 percent in three years. ${ }^{156}$

\footnotetext{
${ }^{154}$ National Football League, 'NFL Clubs to Implement Comprehensive Program to Promote Diversity in Hiring' (Dec. 20, 2002) <https://www.nfl.info/nflmedia/News/2002News/NFLDiversityProgram.htm> accessed 2 October 2013.

${ }^{155}$ Brent A. Maravent, 'Is the Rooney Rule Affirmative Action? Analyzing the NFL's Mandate to Its Clubs Regarding Coaching and Front Office Hires' (2006) 13 Sports Lawyers J. 233, 240-241.

${ }^{156}$ Janice F. Madden and Matthew Ruther, 'Has the NFL's Rooney Rule Efforts "Leveled the Field" for African American Head Coach Candidates?' (2010) 12(2) J. of Sports Econ.127. But compare Benjamin L. Solow et. al., 'Moving on Up: The Rooney Rule and Minority Hiring in the NFL' (2011) 18(3) Labour Econ. 332.
} 
Pursuant to the Rooney Rule, the NFL also issued a series of guidelines for interviewing head coaches. Among the suggested practices, teams are required to clearly and fully define the role of the coach and the qualities needed for the position, set forth a timeline for the search process including key decisions and dates, and identify a deep and diverse pool of candidates using a variety of criteria for diversity. ${ }^{157}$ In relation to identifying diverse candidates, the NFL guidelines further provide that teams should be knowledgeable about both internal and external minority candidates. ${ }^{158}$ Moreover, failure to adhere to the Rooney Rule's requirements is punishable by a fine for the team and personal liability for the executives involved. ${ }^{159}$

\section{b) A Rooney Rule for Boards}

The premise of the Rooney Rule seems equally applicable to the appointment of women to boards. Instead of imposing quotas, legislation could be introduced that mandates that board nominating committees interview at least one female candidate for every board opening. In addition, similar to the guidelines under the Rooney Rule, board nominating committees could be required to define the role and qualities of directors and seek out a pool of candidates using a variety of criteria for diversity, one of which must be gender. Moreover, the legislation could be extended to executive search firms, who are commonly involved in board appointments processes, such that the firms would be required to supply at least one female candidate for every three male candidates they recommend.

Enforcement of the rule would likely be by way of two routes. First, either executive search firms or members of the nominating committee themselves could notify the authorities if a firm fails to interview a female candidate. Second, firms with a low representation of

\footnotetext{
${ }^{157}$ Maravent (n 155) 242.

158 Ibid.

${ }^{159}$ ibid 242-243.
} 
female members on the board could be required to submit to yearly audits in which they would have to evidence their practices for recruiting women to the board, including information on the number of women interviewed, summaries of the interviewed women's qualifications, and reasons for not hiring the women interviewed. Moreover, sanctions for failing to adhere to these practices could be similar to those imposed under the Rooney Rule where the team and the team's owner have both been fined. ${ }^{160}$ Similarly, for companies that fail to interview women for board positions, both the firm and the CEO or managing director could be fined.

A Rooney Rule for boards boasts a number of different advantages over the use of quotas. First, as it is directed at improving equality of opportunity but does not mandate a required result, it may be perceived by businesses and boards as a more just solution than quotas. While quotas mandate explicit hiring preferences, the Rooney Rule only sets aside interviews for minorities. Thus, the minority candidate does not gain an advantage when it comes to the final selection, but must, instead, compete with all the other qualified applicants for the position. ${ }^{161}$

In this way, the Rooney Rule is aimed only at levelling the playing field or providing for a more just basis for fair competition. This still enables the best candidate - male or female - to rise to the top. It is thus not akin or proximate to a legislative quota which would guarantee the appointment of a woman as the gender of the ultimately selected director is not prescribed. ${ }^{162}$ Indeed, nominating committees can continue to appoint directors on the basis of qualifications rather than gender.

\footnotetext{
${ }^{160}$ CBS, 'Lions' Millen Fined \$200K for Not Interviewing Minority Candidates' (25 July 2003) <http://cbs.sportsline.com/print/nfl/story/6498949> accessed 2 October 2013.

${ }^{161}$ BrianW. Collins, 'Tackling Unconscious Bias In Hiring Practices: The Plight of The Rooney Rule' (2007) 82 NYU L. Rev. 870 (note).

162 The House of Lords EU Select Committee expressed concerns that a Rooney rule for boards would "undercut work so far because of its perceived proximity to legislative quotas". House of Lords - European Union Committee (n 39) para. 120.
} 
Second, because, unlike quotas, a Rooney Rule for boards emphasises the individual skills and attributes of a female candidate instead of her gender, boards are less likely to view women as a demographic statistic. Women appointed to boards are therefore more likely to be viewed as equals and to be accepted by board members. As the rebolstered economic rationale argued above indicates, acceptance by and viewing of women as equals by other board members both increases board cohesiveness and enables women's contributions to board discussions to be valued by board members. ${ }^{163}$ Conversely, quotas may put appointed women in hostile environments in which the other board members view her as primarily a "quota-filling member" rather than an individual appointed on merit. ${ }^{164}$ At the same time, a woman appointed under a Rooney Rule will also view her appointment as being one achieved on merit. This may instil greater confidence in her, making her more likely to exercise influence over board dynamics.

Third, use of the Rooney Rule may enable nominating committees to circumvent the problems of unconscious bias that arise during the selection process previously discussed. ${ }^{165}$ While similarities between the selector and the candidate may still initially dominate as proxies of trust, by being exposed to qualified women, the selectors may gradually be able to identify other non-biased factors for trust, enabling them to appoint a wider variety of individuals to boards rather than those that act, look and sound like them.

Finally, a Rooney Rule for boards is also more likely to bring about a normative shift regarding the value of women as board members than under a quota system. If those who are resistant to the notion of women on boards are required to consider qualified women for board positions, it is more likely that they will see the merits that women can offer. It is thus,

\footnotetext{
${ }^{163}$ Sabina Nielsen and Morten Huse, 'Women Directors' Contribution To Board Decision-Making and Strategic Involvement: The Role of Equality Perception' (2010) 7 European Management Rev.16, 27 (arguing that where women are not viewed as equals by their colleagues, women's unique contributions to boards are disregarded by other board members).

${ }^{164}$ Catherine Casey et al., 'Gender Equality and Corporate Governance: Policy Strategies in Norway and New Zealand' (2011) 18(6) Gender, Work and Organization 613, 626.

${ }^{165}$ See the discussion on unconscious bias in Part I.C.
} 
an exercise, far and above, one of box-ticking. ${ }^{166}$ Indeed, over time, it is more likely to prompt an attitudinal shift than a self-regulatory or voluntary approach.

\section{ii. Increasing Supply}

In addition to introducing the Rooney Rule to increase the demand for minority head coaches, the NFL introduced a new program to create a supply of qualified individuals. This came in the form of a coaching fellowship program designed to prepare individuals to take on the responsibilities of a head coaching position. ${ }^{167}$ Increasing the demand for women on boards through use of a Rooney Rule styled initiative must, similarly, be complemented by initiatives that promote the supply of qualified women for these positions. ${ }^{168}$

\section{a) Creating a Database}

In part, adopting a Rooney Rule for boards may, in and of itself, address the supply problem. If companies are mandated to interview female candidates, there may be more impetus to home groom women who could later help companies meet this requirement. For example, National Grid plc has already adopted its own variant of a Rooney Rule by having a policy in place that provides that a third of the candidates put forward for mid-level management positions must be female. ${ }^{169}$ Nevertheless, for those companies that are more resistant to change - in addition to board mentorship and training programs already advocated in Lord Davies' report - further measures may be necessary to ensure a steady stream of qualified women.

\footnotetext{
${ }^{166}$ One commentator noted that a Rooney rule for boards would lead to "a woman being added just to put a tick in the box, which effectively would be a waste of everyone's time and disrespectful to the female candidates". See House of Lords - European Union Committee (n 39) para. 119. ${ }^{167}$ Maravent (n 155) 241.

${ }^{168}$ Although a pipeline of qualified individuals has already been identified by the Cranfield School of Management, the need to perpetuate the pipeline remains important. See Cranfield School of Management ( $\mathrm{n}$ 22).

${ }^{169}$ Louise Peacock, 'Investors 'not concerned' about women on boards, say FTSE 100 bosses' The Telegraph (London, 3 Nov 2011).
} 
One option would be to implement a nation-wide database that houses the information of qualified female board candidates. Private organisations in both the United States and Norway have already compiled databases in which women interested in board positions can voluntarily submit their details ${ }^{170}$ as has London-based "High Tech Women" and the Cranfield School of Management. ${ }^{171}$ The Tyson report, has, however, previously rejected the use of databases. The Report cited concerns about the growing number of databases and pointed to a poor experience with a public sector database, used in the past, whose organiser became increasingly involved with commercial activities. ${ }^{172}$

Yet, a centralised government-run database may, despite the Tyson report's critiques, still offer a number of advantages. First, unlike the privately run databases, a government database would centralise the information of all aspiring female board candidates. Thus, firms would be able to have one source from which they could locate female candidates, thereby minimising their transaction costs. In fact, the database could be funded by imposing a yearly maintenance fee on firms, while female candidates could voluntarily register their information for free. ${ }^{173}$

Second, women in the so-called 'pipeline' - those in upper level and senior management positions - could be encouraged to register with the database in order to monitor the progression of women to boards. By centralising the information, moreover, women at each level of the progression of women to boards could be monitored. Consequently if deficiencies were then identified at any level, government initiatives specifically targeted at

\footnotetext{
${ }^{170}$ See e.g., InterOrganization Network, 'ION Partners with GMI to Give Members Access to Diverse Directors DataSource (3D)' (July 25, 2011) <http://gmi3d.com/about/pr/ION_GMI_Release_072511_Final1.pdf> accessed 2 October 2013; Confederation of Norwegian Enterprise, Female Future: Mobilizing Talents - A Business Perspective (2007) 4

<http://www.nho.no/getfile.php/global/konvertert/NHO/RootNY/filer_og_vedlegg1/femalefuture-englishweb.pdf> accessed 2 October 2013.

${ }^{171}$ High Tech Women, 'High Tech Women Pool of Directors' (Undated)<http://hightechwomen.com/poolofdir.html> accessed 2 October 2013; House of Lords - European Union Committee (n 39) para. 131.

172 Tyson (n 11) 9-10.

173 This was an approach suggested to the House of Lords, EU Select Committee which seems to have met with their approval. See House of Lords - European Union Committee (n 39) para. 138.
} 
that level could be strengthened. Finally, the mandate of the host of the database could be restricted to simply organising and monitoring the information on the database and prohibited from engaging in commercial activities. This limited mandate would eliminate the problem that arose with the previously used public sector database.

\section{b) Social and Institutional Measures}

While a database of qualified candidates may descriptively demonstrate the supply of women that are available, to truly ensure a supply of qualified women, gender parity initiatives must be complemented by supplementary measures that address the factors which have traditionally limited women's participation in business. ${ }^{174}$ As the equality rationale, discussed previously, reveals, women's fair equality of opportunity to participate in business may be limited by existing social and institutional arrangements.

There are principally two main factors that limit women's opportunities to participate in business at a leadership level. The first is women's double burden, or the combination of work and domestic responsibilities. ${ }^{175}$ As primary responsibility for family life still tends to rest on women, women are required to fulfil work responsibilities in addition to domestic responsibilities such as child care, house work, care of the elderly, etc. The 'double burden' is thus incompatible for many women with the demands associated with positions of leadership in business.

The second factor is the job model for success. Positions of leadership in business tend to be achieved through a model in which unfailing availability and total geographical mobility at all times is required in addition to a linear career path with no breaks. ${ }^{176}$ This model prizes career before family life, thereby penalising women who take breaks such as

\footnotetext{
${ }^{174}$ Manuel F. Bagues and Berta Esteve-Volart, 'Can Gender Parity Break the Glass Ceiling? Evidence from a Repeated Randomized Experiment' (2010) 77:4 Rev. of Econ. Studies1301; Charlotte L. Villiers, 'Achieving Gender Balance in the Boardroom: Is it Time for Legislative Action in the U.K.?' (2010) 30(4) LS 533, 551. ${ }^{175}$ Desvaux et al. (n 54) 7.

${ }^{176}$ ibid; Kornberger et al. (n 55) 775, 788-89; Ashley and Empson (n 55).
} 
maternity leave. ${ }^{177}$ Moreover, women who achieve success by following this model may also pay a much higher price than men. Thus, while men in positions of leadership are likely to be married and to have children, more than half of women in positions of leadership do not have children and one third of them are unmarried. ${ }^{178}$

Curiously, although companies have found that they have been unable to retain women at senior levels because of the inflexibility of this job model, there have been few attempts to change it. Instead, attempts to increase the progression of women in business at senior levels have focused on encouraging women to embrace the current job model. ${ }^{179}$ Yet because the existing job model has contributed to problems with equality in the first place, attempts to eradicate inequalities in this way have resulted in paradoxical outcomes. ${ }^{180}$

Based on these identified limitations to women's participation in business, achieving a sustainable supply of qualified women for boards requires changes both to support systems as well as a reconfiguration of the model for success. Thus, changes must be made to alleviate women's double burden. This should include, as a starting point, better access to affordable child care, as limitations on child care facilities have been found to limit women's participation in the labour force. ${ }^{181}$ Government measures should accordingly be directed at either creating additional child care facilities or lowering the costs of existing facilities as well as policies which help families share child care, such as improved paternity leave.

In addition, the model of success must also be revised. Amending the existing job model to facilitate flexible working conditions such as flexibility in terms of time and place is essential to promoting women into senior positions in business. Indeed, since the current job model for success has contributed to the inability of firms to retain women at senior levels in

\footnotetext{
${ }^{177}$ Desvaux et al. (n 54) 8.

${ }^{178}$ ibid 16.

179 ibid 14-15; Kornberger et al. (n 55); Ashley and Empson (n 55).

${ }^{180}$ Ashley and Empson (n 55).

${ }^{181}$ Arnaud Chevalier and Tarja K. Viitanen, 'The Causality Between Female Labour Force Participation and the Availability of Childcare' (2002) 9 Applied Econ. Letters 915; Karen O. Mason and Karen Kuhlthau, 'The Perceived Impact of Child Care Costs on Women's Labour Supply and Fertility'(1992) 29 Demography 523.
} 
business, failing to revise the model will ensure that there will continue to be deficiencies in the supply of qualified women.

As the equality rationale, earlier posited, highlights, without structural changes to the mechanisms that gave rise to the under-representation of women at higher levels of business in the first place, initiatives to increase the number of women on boards are not sustainable. Only by changing the social and institutional arrangements that may have compromised women's participation in the labour market will measures to increase women on boards be more than mere window dressing. For this reason, if the government is truly committed to having gender diverse boards, it is insufficient for them to place the onus only on companies to make changes at the board level. While companies can play a pivotal role in this arena, it is the state which retains key responsibility for breaking down structural barriers in the labour market and facilitating women's participation in it.

\section{Conclusion}

Measures to increase the number of women on boards have been described as both the 'right' thing and the 'bright' thing. ${ }^{182}$ In truth, rationales justifying measures in this area should only have to demonstrate how they promote the 'right' thing, or in other words, be entirely justified in terms of equality and justice. It is only because the support of the business community is essential to effect change in this area that demonstrating the economic benefits of having women on the boards remains an important - albeit secondary - rationale.

Recognizing the hierarchy of rationales justifying reforms in this area further demonstrates the problems with relying on the government's preference for an exclusive

\footnotetext{
${ }^{182}$ See e.g. Conference Board of Canada, Women on Boards - Not Just the Right Thing . . But the "Bright" Thing (Conference Board of Canada 2002).
} 
business-led approach. Promoting equality is unlikely to be a motivating factor for companies to make the normative changes that will result in increasing the number of female directorships in the long run. Thus, the recent increases that have been made to the number of women on boards are unlikely to be sustainable in the long run.

Instead, because considerations of equality are the predominant reason for instituting measures in this arena, the government must play an important role in this area alongside business. While the predominant free-market ideology espoused by the market would likely abhor severe governmental intervention, it is more likely to accept government efforts which facilitate companies' work in this area. For this reason, measures such as promulgating a Rooney rule for boards, creating a database of qualified women and breaking down institutional and social barriers to better ensure women's fair equality of opportunity to participate in business are limited means by which the government could assist companies' work in this area.

While a business-led approach has made some short-term improvements to board composition, it has not resulted in the substantive normative changes needed to produce a sustainable solution to the problem. It is therefore time for the government to take on a greater role in this matter as issues of equality are too important to be left solely in the hands of business. 